\title{
Establishment and evaluation of transgenic models of Alzheimer's disease with senescence accelerated background
}

\author{
Wenjuan Zhao ${ }^{\dagger}$, KengHoe Lok ${ }^{\dagger}$, Hong Zhao, Anyang Sun, Ming Yin ${ }^{*}$ \\ From 2011 International Conference on Molecular Neurodegeneration \\ Shanghai, China. 22-24 September 2011
}

\begin{abstract}
Background
Although transgenic animal models of Alzheimer's disease $(\mathrm{AD})$ have proven to be relatively faithful models for neuropathological changes, none completely recapitulate the disease process. We aimed to establish new AD transgenic models with senescence accelerated mouse prone 8 (SAMP8) background.
\end{abstract}

\section{Method}

In the experiments, APP/PS1 and tau ${ }^{\mathrm{P} 301 \mathrm{~L}}$ transgenic mice of $\mathrm{C} 57 \mathrm{BL} / 6 \mathrm{~J}$ background were interbred with SAMP8 mice for five generations. Gene identification of filial generation was tested by PCR. The grading score system developed by Takeda $\mathrm{T}$ et al was used for evaluation of the degree of senescence in mice. The agerelated decline of learning and memory ability was analyzed using passive avoidance shuttle box and Morris water maze tasks. Immunofluorescence study was performed to ascertain the presence of $\beta$-amyloid $(A \beta)$ and tau pathology in $\mathrm{AD}$ mouse models by using $\beta$-amyloid antibody and specific phosphorylated tau antibody at Ser404.

\section{Results}

Both APP/PS1 and tau ${ }^{\text {P301L }}$ transgenic mice in SAMP8 background exhibited accelerated aging with a high grading score. The transgenic mice with SAMP8 background also exhibited age-dependent cognitive impairments, compared with transgenic mice with C57BL/6J background or wild mice with SAMP8 background at the same age. In shuttle box avoidance task, tau ${ }^{\text {P301L }}$

\footnotetext{
* Correspondence: myin@sjtu.edu.cn

+ Contributed equally

Laboratory of Neuropharmacology, School of Pharmacy, Shanghai Jiao Tong

University, 200240, Shanghai, China
}

transgenic mice with SAMP8 background had obvious memory deficit very early in life, approximately at the age of 6-month old. Probe trial in Morris water maze test showed a marked deficit in the APP/PS1 transgenic mice with SAMP8 background, which spent less time at platform quadrant, compared with APP/PS1 transgenic mice with $\mathrm{C} 57 \mathrm{BL} / 6 \mathrm{~J}$ background or wild mice with SAMP8 background at the same age of 9-month old. In immunohistochemistry studies, SAMP8 mice showed sporadic $A \beta$ deposition in the hippocampus, cortex and thalamus from as early as 6-month old, and increase in number and extent with age. Significant elevation of $A \beta$ deposition in the whole brain, even extent to the cerebellum and spinal cord of 6-month-old APP/PS1 transgenic mice with SAMP8 background could be seen. We also found that obvious immunofluorescent staining of phosphorylates tau at Ser404 (PHF-tau) in the hippocampus, cortex and thalamus 9-month-old tau ${ }^{\text {P301L }}$ transgenic with SAMP8 background. However, no obvious phosphorylated tau were found in wild SAMP8 mice or tau ${ }^{\mathrm{P} 301 \mathrm{~L}}$ transgenic $\mathrm{C} 57 \mathrm{BL} / 6 \mathrm{~J}$ mice even at the age of 9 months, when compared with wild C57BL/6J mice.

\section{Conclusion}

The characterized neuropathological alterations and cognitive impairment in $\mathrm{AD}$ can be reproduced genetically early in transgenic mice over-expressing APP/PS1 or tau ${ }^{\mathrm{P} 301 \mathrm{~L}}$ genes with senescence accelerated background. These novel mouse models for $\mathrm{AD}$ will help to clarify the pathogenic mechanism and allow assessment of the effects of new treatment strategies. 


\section{Acknowledgements}

This study was supported by Science and Technology Commission of Shanghai Municipality scientific innovation project No. 09140901900 and NSFC No. 30970685.

Published: 7 February 2012

doi:10.1186/1750-1326-7-S1-S34

Cite this article as: Zhao et al:: Establishment and evaluation of

transgenic models of Alzheimer's disease with senescence accelerated background. Molecular Neurodegeneration 2012 7(Suppl 1):S34.

Submit your next manuscript to BioMed Central and take full advantage of:

- Convenient online submission

- Thorough peer review

- No space constraints or color figure charges

- Immediate publication on acceptance

- Inclusion in PubMed, CAS, Scopus and Google Scholar

- Research which is freely available for redistribution

Submit your manuscript at www.biomedcentral.com/submit
() Biomed Central 